\title{
Modeling and Energy Consumption of Unilateral Heating Process of Flat Wood Details
}

\section{Modeliranje i potrošnja energije u procesu jednostranog zagrijavanja ravnih drvenih elemenata}

\author{
Preliminary paper - Prethodno priopćenje \\ Received-prispjelo: 6. 3. 2015. \\ Accepted-prihvaćeno: 6. 9. 2016. \\ UDK: $630 * 812.145$ \\ doi:10.5552/drind.2016.1518
}

\begin{abstract}
A methodology has been suggested for mathematical modeling and research of two mutually connected problems: the temperature distribution along the thickness of flat wood details subjected to unilateral heating and the energy consumption of this process. For the realization of the methodology, a 1-dimensional mathematical model has been created and solved for the transient linear heat conduction in flat wood details during their unilateral heating at arbitrary initial and boundary conditions encountered in the practice. Based on the integration of the model's solutions, a numerical approach has been suggested for the computation of the specific energy consumption (for $1 \mathrm{~m}^{2}$ ) and the specific heat flux needed for the heating of the details and for the covering of their heat emission in the surrounding environment during unilateral heating aimed at wood plasticizing and bending. This paper presents solutions of the model concerning the non-stationary temperature distribution along the thickness of spruce details with thicknesses of 6,8 and $10 \mathrm{~mm}$ and the non-stationary change in the specific energy consumption and in the specific heat flux during unilateral heating at temperatures of the electrically heated metal band equal to 100,120 , and $140{ }^{\circ} \mathrm{C}$ aimed at plasticizing and bending of the details in the production of outside curved parts of the body of string musical instruments. The obtained results can be used for technological and energy calculations and for analysis of processes of unilateral heating of wood details at different boundary conditions, as well as in software for systems for model based automatic control of such processes aimed at bending of the heated and plasticized details.
\end{abstract}

Key words: unilateral heating, modeling, wood details, plasticizing, bending, specific energy consumption

\begin{abstract}
SAŽETAK• Autori u radu daju prijedlog metodologije za matematičko modeliranje i istraživanje dvaju međusobno povezanih problema: raspodjele temperature u smjeru debljine ravnih drvenih elemenata izloženih jednostranom zagrijavanju i potrošnje energije tog procesa. Za realizaciju metodologije izrađen je jednodimenzionalni matematički model $i$ riješen za linearni tok topline pri provođenju topline u ravnim drvenim elementima za vrijeme njihova proizvoljnoga jednostranog zagrijavanja, s početnim i rubnim uvjetima koji se mogu susresti u praksi. Na temelju integracije rješenja modela, predložena je numerička metoda za izračunavanje specifične potrošnje energije (za $\left.1 \mathrm{~m}^{2}\right)$ i specifičnoga toplinskog toka potrebnoga za zagrijavanje elemenata i za nadoknađivanje emisije topline u okolinu za vrijeme jednostranoga grijanja radi plasticiranja i lakšeg savijanja drva.
\end{abstract}

\footnotetext{
${ }^{1}$ Authors are professor, associate professor and associate professor at University of Forestry, Faculty of Forest Industry, Sofia, Bulgaria. ${ }^{2} \mathrm{Au}-$ thor is professor at Technical University in Zvolen, Faculty of Wood Science and Technology, Zvolen, Slovakia.

Autori su profesor, izvanredni profesor i izvanredni profesor Šumarskog sveučilišta, Fakultet drvne industrije, Sofija, Bugarska. ${ }^{2}$ Autor je profesor Tehničkog sveučilišta u Zvolenu, Fakultet znanosti o drvu i drvne tehnologije, Zvolen, Slovačka.
} 
U radu su prikazana rješenja modela koja se odnose na nestacionarnu raspodjelu temperature smrekovih elemenata debljine 6, 8 i $10 \mathrm{~mm}$ po debljini i na nestacionarnu promjenu specifične potrošnje energije i specifičnoga toplinskog toka za vrijeme jednostranog zagrijavanja na temperature električno grijane metalne trake koje su iznosile 100, $120 \mathrm{i} 140^{\circ} \mathrm{C}$. Elementi su zagrijavani radi plasticiranja i savijanja drvenih elemenata u proizvodnji vanjskih zakrivljenih dijelova korpusa žičanih glazbenih instrumenata. Dobiveni se rezultati mogu koristiti za tehnološke $i$ energetske izračune $i$ za analizu procesa jednostranog zagrijavanja drvenih elemenata u različitim rubnim uvjetima, kao i za softver za modeliranje sustava koji se temelji na automatskom upravljanju procesima usmjerenima na savijanje zagrijanih i plastificiranih drvenih elemenata.

Ključne riječi: jednostrano grijanje, modeliranje, drveni elementi, plastificiranje, savijanje, specifična potrošnja energije

\section{INTRODUCTION}

1. UVOD

An important mandatory component of technologies for the production of curved wood details in furniture industry and others is their plasticizing up to the stage that allows for their faultless bending (Angelski, 2010). The current applications of such technologies differ mainly by the method selected for plasticizing wood (by heating using water steam, hot water, heated metal curved surfaces, or high frequency electric current).

The method for plasticizing wood details before their bending is chosen primarily based on economic reasons and according to the values of the relationship $R / h$, where $R$ is the radius of bending curvature of the concave side of the details, and $h$ is the size of the cross section of details in the direction coinciding with the bending plane.

During the bending of details with large radii of curvature at $R / h>20$, the wood need not have a large degree of plasticity. In this case, from technological and economical standpoints, it is most advantageous to plasticize the wood using unilateral heating at relatively low wood moisture content in the range from $12 \%$ to $20 \%$ (Rowell and Konkol, 1987; Rice and Lucas, 2003). Plasticizing with such, relatively low, wood moisture content ensures considerable decreasing of the duration of the drying of the bent details aimed at providing lasting stabilization of their form.

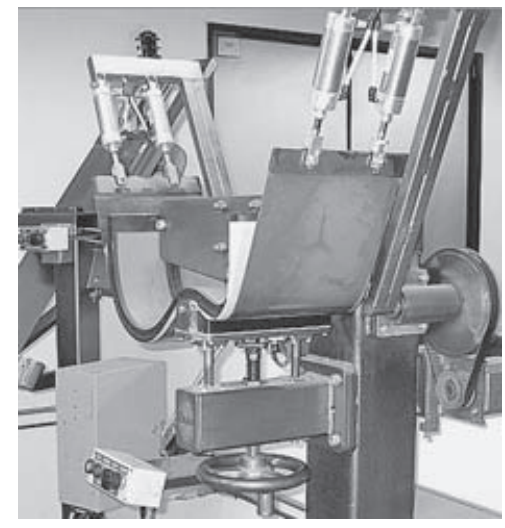

Figure 1 Equipment with electrically heated band for unilateral heating and bending of flat wood details in the production of outside curved parts for bodies of string musical instruments

Slika 1. Oprema s električno grijanom trakom za jednostrano zagrijavanje i savijanje ravnih drvenih elemenata u proizvodnji vanjskih zakrivljenih dijelova korpusa gudaćih instrumenata
Unilateral heating of wood details is most often carried out in the specific equipment used for bending. For such heating of details with thicknesses between 10 and $25 \mathrm{~mm}$, hot hydraulic presses with appropriately bent surfaces are usually used. Curved details for the back parts of chairs are produced, for example, by this method of plasticizing. These details have a relatively small thickness, a large radius of curvature and $R / h$ ratio $=20-25$.

In the production of curved outside parts for the bodies of string musical instruments (violins, guitars, mandolins, violoncellos), details with thickness between $5 \mathrm{~mm}$ and $10 \mathrm{~mm}$ and with a $15 \%$ moisture content are subjected to bending. The technology for plasticizing of such details usually uses equipment with metal band, electrically heated up to the temperature in the range from $100{ }^{\circ} \mathrm{C}$ to $150{ }^{\circ} \mathrm{C}$ (Figure 1).

It is known that the degree of plasticizing and deformability of the wood depends considerably on the temperature distribution in the details' volume at the moment of bending. The non-stationary temperature distribution in the details and the specific energy consumption during their unilateral heating, aimed at the details' plasticizing before bending, depends on many factors: wood species, thickness and moisture content of the details, temperatures of the heating medium (body) and of the surrounding air, desired degree of plasticizing, radius of the bending, etc. (Chudinov, 1968; Shubin, 1990; Požgaj et al., 1997; Taylor, 2001; Trebula and Klement, 2002; Deliiski, 2003, 2013b; Videlov, 2003; Pervan, 2009; Angelski, 2010; Deliiski and Dzurenda, 2010; Gaff and Prokein, 2011).

In the specialized literature, there is little data available about the temperature distribution in wood details subjected to multilateral heating with water steam before bending (Angelski, 2010) and there is no information at all about the temperature distribution in details during their unilateral heating. Information about the energy consumption needed for the heating of wood details during their unilateral heating was provided only by the authors (Deliiski et al., 2014). In the cited publication, an approach for the calculation of the specific energy consumption needed only for the wood heating in $\mathrm{kWh} \cdot \mathrm{m}^{-3}$ was presented and there is no information about the energy needed for the covering of the heat emission from the non-heated side of wood details.

That is why the modeling and energy consumption of the processes of unilateral heating of wood details, as well as the multiparameter study of these pro- 
cesses, are of considerable scientific and practical interest. For the practical needs, it is more convenient to determine the total energy consumption during unilateral heating of flat details in $\mathrm{kWh} \cdot \mathrm{m}^{-2}$ instead in $\mathrm{kWh} \cdot \mathrm{m}^{-3}$.

The aim of the present paper is to suggest a methodology for mathematical modeling and research of two mutually connected problems: the temperature distribution in flat wood details subjected to unilateral heating and the energy consumption of this process.

The paper presents the development and solution of 1-dimentional mathematical model of the transient linear heat conduction in flat wood details during their unilateral heating at arbitrary initial and boundary conditions encountered in the practice. Based on the integration of the model's solutions, for the first time a numerical approach will be suggested for the computation of the specific (for $1 \mathrm{~m}^{2}$ ) energy consumption and the specific heat flux needed for the heating of the details and for the covering of their heat emission during unilateral heating aimed at wood plasticizing and bending.

The paper also presents the results of simulation research of the non-stationary temperature distribution along the thickness of spruce details with $h=6,8$ and $10 \mathrm{~mm}$ and the non-stationary change in the specific energy consumption and in the heat flux during unilateral heating at temperatures of the electrically heated metal band $t_{\mathrm{m}}=100,120$, and $140^{\circ} \mathrm{C}$ aimed at plasticizing and bending of the details in the production of outside curved parts for the bodies of string musical instruments.

\section{MATERIAL AND METHODS} 2. MATERIJAL I METODE

\subsection{Modeling of heat distribution in flat wood} details during their unilateral heating

2.1. Modeliranje raspodjele topline u ravnim drvenim elementima tijekom jednostranog zagrijavanja

When the width and length of wood details exceed their thickness by at least 3 and 5 times, respectively, then the change in the temperature only along the thickness of the details in the center of their flat side during unilateral heating (i.e. along the coordinate $x$, which coincides with the details thickness $h$ ) can be calculated with the help of the following linear 1D mathematical model (Deliiski, 2003, 2011, 2013b):

$$
\frac{\partial T(x, \tau)}{\partial \tau}=a_{\mathrm{w}}\left(T, u, u_{\mathrm{fsp}}, \rho_{\mathrm{b}}, S_{\mathrm{v}}\right) \cdot \frac{\partial^{2} T(x, \tau)}{\partial x^{2}}
$$

$$
T(x, 0)=T_{0}
$$

and following boundary conditions:

- from the side of the details heating - at prescribed surface temperature, which is equal to the temperature of the metal heating band $T_{\mathrm{m}}$ :

$$
T(0, \tau)=T_{\mathrm{m}}(\tau)
$$

- from the opposite non-heated side of the details - at convective heat exchange between the details surface and the surrounding air environment

$$
\frac{\partial T(X, \tau)}{\partial x}=-\frac{\alpha}{\lambda_{\mathrm{ws}}\left(T, u, \rho_{\mathrm{b}}\right)} \cdot\left[T_{\mathrm{ws}}(\tau)-T_{\mathrm{a}}(\tau)\right]
$$

For practical use of eqs. (1) and (4), it is necessary to have mathematical descriptions of wood temperature conductivity, $a_{\mathrm{w}}$, of wood thermal conductivity, $\lambda_{\mathrm{w}}$, and of the heat transfer coefficient between the details surface at their non-heated side and the surrounding air, $\alpha$. For this purpose, the mathematical description of $a_{\mathrm{w}}$ and $\lambda_{w}$ of non-frozen wood given in (Deliiski, 2003, 2013a; Deliiski et al., 2015) can be used.

The heat transfer coefficient, $\alpha$ can be calculated with the help of the following equation, which is valid for the cases of cooling or heating of horizontally situated rectangular surfaces in atmospheric conditions of free convection (Chudinov, 1968; Telegin et al., 2002):

$$
\alpha=3.256 \cdot\left[T_{\mathrm{ws}}(\tau)-T_{\mathrm{a}}(\tau)\right]^{0.25}
$$

According to eq. (3), the temperature at the details surface, which is in contact with the heating metal band, is accepted to be equal to its temperature $T_{\mathrm{m}}$ due to the extremely high coefficient of heat transfer between the band and the wood during their very close contact.

\subsection{Modeling of the total specific energy consumption for unilateral heating of wood details}

2.2. Modeliranje ukupne specifične potrošnje energije za jednostrano zagrijavanje drvenih elemenata

The total specific energy consumption for unilateral heating of wood details, $q_{\text {total }}$, consists of two components:

- energy needed for heating of the wood itself, $q_{\mathrm{w}}$;

- energy needed for the covering of the heat emission from the non-heated side of wood details, $q_{\mathrm{e}}$.

This means that the energy $q_{\text {total }}$ can be calculated according to the following equation:

$$
q_{\text {total }}=q_{\mathrm{w}}+q_{\mathrm{e}} .
$$

Analogously, the total heat flux needed for unilateral heating of wood details, $\mathrm{d} q_{\text {total }} / \mathrm{d} \tau$, can be calculated according to the equation

$$
\frac{\mathrm{d} q_{\text {total }}}{\mathrm{d} \tau}=\frac{\mathrm{d} q_{\mathrm{w}}}{\mathrm{d} \tau}+\frac{\mathrm{d} q_{\mathrm{e}}}{\mathrm{d} \tau} .
$$

\subsubsection{Modeling of the specific energy}

consumption for heating of the wood itself

2.2.1. Modeliranje specifične potrošnje energije samo za zagrijavanje drva

It is known that the specific energy consumption for heating $1 \mathrm{~m}^{3}$ of solid wood with an initial mass temperature $T_{0}$ to a given average mass temperature $T_{\text {avg }}$ is determined using the equation (Deliiski, 2013b; Deliiski et al., 2014)

$$
q=\frac{c_{\mathrm{w}}(T, u) \cdot \rho_{\mathrm{w}}\left(\rho_{\mathrm{b}}, u, u_{\mathrm{fsp}}\right)}{3.6 \cdot 10^{6}} \cdot\left(T_{\mathrm{avg}}-T_{0}\right) .
$$

After multiplying the right part of eq. (8) by the detail thickness $h$, the following equation is obtained for the determination of the specific mass energy con- 
sumption needed for heating $1 \mathrm{~m}^{2}$ of wood details subjected to unilateral heating, $q_{\mathrm{w}}$ :

$$
\begin{gathered}
q_{\mathrm{w}}=\frac{c_{\mathrm{w}}(T, u) \cdot \rho_{\mathrm{w}}\left(\rho_{\mathrm{b}}, u, u_{\mathrm{fsp}}\right) \cdot h}{3.6 \cdot 10^{6}} \cdot\left(T_{\mathrm{avg}}-T_{0}\right), \\
\text { where } \quad \\
T_{\mathrm{avg}}=\frac{1}{h} \int_{(h)} T(x, \tau) \mathrm{d} x
\end{gathered}
$$

and according to Chudinov (1968) and Deliiski (2013b)

$$
\rho_{\mathrm{w}}=\rho_{\mathrm{b}} \cdot \frac{1+u}{1-\frac{S_{\mathrm{v}}}{100} \cdot\left(u_{\mathrm{fsp}}^{293.15}-u\right)} @ u \leq u_{\mathrm{fsp}} .
$$

The multiplier $3.6 \cdot 10^{6}$ in the denominator of eq. (9) ensures that the values of $q_{\mathrm{w}}$ are obtained in $\mathrm{kWh} \cdot \mathrm{m}^{-2}$, instead of in $\mathrm{J} \cdot \mathrm{m}^{-2}$.

The change in $q_{\mathrm{w}}$ during the time $\Delta \tau$, i.e. the heat flux needed for heating $1 \mathrm{~m}^{2}$ of wood details subjected to unilateral heating, $\mathrm{d} q_{\mathrm{w}} / \mathrm{d} \tau$ (in $\mathrm{kW} \cdot \mathrm{m}^{-2}$ ), can be calculated according to equation

$$
\frac{\mathrm{d} q_{\mathrm{w}}}{\mathrm{d} \tau} \approx \frac{3600 \cdot \Delta q_{\mathrm{w}}}{\Delta \tau}
$$

For practical use of eqs. (9) and (12), it is necessary to have a mathematical descriptions of the specific heat capacity of the non-frozen wood, $c_{w}$. Such descriptions are given in (Deliiski, 2003, 2011, 2013b; Deliiski et al., 2015; Radmanović et al., 2014; Deliiski and Dzurenda, 2010).

\subsubsection{Modeling of specific energy consumption for covering of the heat emission from the} non-heated side of wood details

2.2.2. Modeliranje specifične potrošnje energije za nadoknađivanje emisije topline nezagrijavane strane drvenih elemenata

The change in the specific energy consumption $q_{\mathrm{e}}$ (for $1 \mathrm{~m}^{2}$ of the details surface), which is required for the covering of the heat emission from the non-heated side of wood details into the surrounding air environment during the time $\Delta \tau$, can be calculated according to the following equation (Deliiski, 2003; Deliiski et. al. 2014a):

$$
\Delta q_{\mathrm{e}}=\frac{\alpha(\tau) \Delta \tau}{3.6 \cdot 10^{6}} \cdot\left[T_{\mathrm{ws}}(\tau)-T_{\mathrm{a}}(\tau)\right] .
$$

The specific energy consumption required for the covering of the heat emission from $1 \mathrm{~m}^{2}$ surface of the details during their unilateral heating with duration $\tau_{\mathrm{p}}=$ $N . \Delta \tau$ is equal to

$$
q_{\mathrm{e}}=\sum_{i=1}^{N} \Delta q_{e i}
$$

The change in $q_{\mathrm{e}}$ during the time $\Delta \tau$, i.e. the heat flux required for the covering of the heat emission from the non-heated side of $1 \mathrm{~m}^{2}$ of wood details subjected to unilateral heating, $\mathrm{d} q_{\mathrm{e}} / \mathrm{d} \tau$ (in $\left.\mathrm{kW} \cdot \mathrm{m}^{-2}\right)$, can be calculated according to equation (Deliiski et al., 2016b)

$$
\frac{\mathrm{d} q_{\mathrm{e}}}{\mathrm{d} \tau} \approx \frac{3600 \Delta q_{\mathrm{e}}}{\Delta \tau} .
$$

\subsection{Transformation of the model to a form} suitable for programming

2.3. Transformacija modela u oblik pogodan za programiranje

The following system of equations was derived by passing to final increases in equations (1) to (5) with the use of the same approach, as well as by the explicit form of the finite-difference method described in Deliiski (2003, 2011, 2013b; Deliiski and Dzurenda, 2010):

$$
\begin{gathered}
T_{i}^{n+1}=T_{i}^{n}+\frac{a_{\mathrm{w}} \Delta \tau}{\Delta x^{2}} \cdot\left(T_{i-1}^{n}+T_{i+1}^{n}-2 T_{i}^{n}\right), \\
T_{i}^{0}=T_{0} @ 1 \leq i \leq \mathrm{M}=9, \\
T_{1}^{n+1}=T_{\mathrm{m}}^{n+1} \\
T_{9}^{n+1}=\frac{T_{8}^{n}+\frac{\alpha^{n} \cdot \Delta x \cdot T_{\mathrm{a}}^{n}}{\lambda_{\mathrm{ws}}}}{1+\frac{\alpha^{n} \cdot \Delta x}{\lambda_{\mathrm{ws}}}}, \\
\alpha^{n}=3.256 \cdot\left[T_{9}^{n}-T_{\mathrm{a}}^{n}\right]^{0.25},
\end{gathered}
$$

where

$$
\begin{gathered}
\Delta x=\frac{h}{M-1}, \\
M=\frac{h}{\Delta x}+1, \\
\Delta \tau \leq \frac{\Delta x^{2}}{a} .
\end{gathered}
$$

The equations (9) and (10) for the computation of the specific energy consumption needed for unilateral heating of wood details results in the following form suitable for programming:

$$
\begin{aligned}
& q_{\mathrm{w}}^{n+1}=\frac{\rho_{\mathrm{w}} \cdot c_{\mathrm{w}} \cdot h}{3.6 \cdot 10^{6}} \cdot\left(T_{\text {avg }}^{n+1}-T_{0}\right), \\
& \text { where } \\
& T_{\text {avg }}^{n+1}=\frac{1}{h} \int_{(h)} T[x,(n+1) \Delta \tau] \mathrm{d} x .
\end{aligned}
$$

The highest precision for the solution of eq. (25) is ensured by the use of the Simpson's method instead of the well- known but less accurate trapezoidal method and the method of Gregori's (Deliiski, 2003). According to this method, eq. (25) obtains the following discrete analogue (Dorn and McCracken, 1972):

$T_{\text {avg }}^{n+1}=\frac{\Delta x}{3}\left(\begin{array}{l}T_{1}^{n+1}+4 T_{2}^{n+1}+2 T_{3}^{n+1}+4 T_{4}^{n+1}+ \\ 2 T_{5}^{n+1}+4 T_{6}^{n+1}+2 T_{7}^{n+1}+4 T_{8}^{n+1}+T_{9}^{n+1}\end{array}\right)$.

Equation (12) for the computation of the specific heat flux needed for unilateral heating of wood details obtains the following form suitable for programming:

$$
\frac{\mathrm{d} q_{\mathrm{w}}^{n+1}}{\mathrm{~d} \tau} \approx \frac{3600 \Delta q_{\mathrm{w}}^{n+1}}{\Delta \tau},
$$

where

$$
\begin{gathered}
\Delta q_{\mathrm{w}}^{n+1}=q_{\mathrm{w}}^{n+1}-q_{\mathrm{w}}^{n}, \\
q_{\mathrm{w}}^{n}=\frac{\rho_{\mathrm{w}} \cdot c_{\mathrm{w}} \cdot h}{3 \cdot 6 \cdot 10^{6}} \cdot\left(T_{\mathrm{avg}}^{n}-T_{0}\right), \\
T_{\mathrm{avg}}^{n}=\frac{\Delta x}{3}\left(\begin{array}{l}
T_{1}^{n}+4 T_{2}^{n}+2 T_{3}^{n}+4 T_{4}^{n}+ \\
2 T_{5}^{n}+4 T_{6}^{n}+2 T_{7}^{n}+4 T_{8}^{n}+T_{9}^{n}
\end{array}\right) .
\end{gathered}
$$


The change in the specific energy consumption $q_{\mathrm{e}}$ (for $1 \mathrm{~m}^{2}$ of the details surface), required for the covering of the heat emission from the non-heated side of wood details into the surrounding air environment during the time $\Delta \tau$, can be calculated according to the following equation (Deliiski 2003, Deliiski et al., 2016b):

$$
\Delta q_{\mathrm{e}}^{n+1}=\frac{\alpha^{n}(\tau) \Delta \tau}{3.6 \cdot 10^{6}} \cdot\left[T_{9}^{n}(\tau)-T_{\mathrm{a}}^{n}(\tau)\right]
$$

Equation (15) for the computation of the specific heat flux needed for the covering of the heat emission from the non-heated side of wood details obtains the following form suitable for programming:

$$
\frac{\mathrm{d} q_{\mathrm{e}}^{n+1}}{\mathrm{~d} \tau} \approx \frac{3600 \cdot \Delta q_{\mathrm{e}}^{n+1}}{\Delta \tau} .
$$

The step on the time coordinate $\Delta \tau$ is determined by keeping the condition for stability of the solution of $1 \mathrm{D}$ models by using the explicit form of the finite difference method (Deliiski, 2003, 2011):

$$
\Delta \tau \leq \frac{\Delta x^{2}}{a_{\mathrm{w}}} .
$$

\section{RESULTS AND DISCUSSION}

\section{REZULTATI I RASPRAVA}

For the numerical solution of the above presented mathematical model, a software program was prepared in FORTRAN in the calculation environment of Visual Fortran Professional.

With the help of the program, as examples, computations were made for the determination of the $1 \mathrm{D}$ non-stationary change of $t, t_{\mathrm{avg}}, q_{\mathrm{w}}, q_{\mathrm{e}}, q_{\mathrm{total}}, \mathrm{d} q_{\mathrm{w}} / \mathrm{d} \tau, \mathrm{d} q_{\mathrm{e}} /$ $\mathrm{d} \tau$, and $\mathrm{d} q_{\text {total }} / \mathrm{d} \tau$ for non-frozen spruce (Picea Abies Karst) details with $h=6 \mathrm{~mm}, h=8 \mathrm{~mm}, h=10 \mathrm{~mm}, t_{0}$ $=20^{\circ} \mathrm{C}, u=0.15 \mathrm{~kg} \cdot \mathrm{kg}^{-1}, \rho_{\mathrm{b}}=380 \mathrm{~kg} \cdot \mathrm{m}^{-3}$, and $S_{\mathrm{v}}=11.4$ $\%$ during their $10 \mathrm{~min}$ unilateral heating at $t_{\mathrm{m}}=100{ }^{\circ} \mathrm{C}$, $t_{\mathrm{m}}=120^{\circ} \mathrm{C}, t_{\mathrm{m}}=140^{\circ} \mathrm{C}$, and at $t_{\mathrm{a}}=20^{\circ} \mathrm{C}$.

The computations were carried out with average values of the spruce temperature conductivity cross-sectional to the fibers, $a_{\mathrm{w}}$, and values of the spruce thermal conductivity cross-sectional to the fibers, $\lambda_{\mathrm{w}}=\lambda_{\mathrm{ws}}$, which have been obtained using the mathematical descriptions of $a_{\mathrm{w}}$ and $\lambda_{\mathrm{w}}$ depending on $t, u$, and $u_{\text {fsp }}$ of the wood species (Deliiski, 2003, 2013a, Deliiski et. al., 2015). The calculated values of $a_{\mathrm{w}}$ and $\lambda_{\mathrm{w}}$ with the help of these mathematical descriptions for spruce wood with $u=$ $0.15 \mathrm{~kg} \cdot \mathrm{kg}^{-1}$ and $u_{\mathrm{fsp}}^{293.15}=0.32 \mathrm{~kg} \cdot \mathrm{kg}^{-1}$ (Nikolov and
Videlov, 1987; Deliiski and Dzurenda, 2010) in the temperature ranges from $20^{\circ} \mathrm{C}$ to $100{ }^{\circ} \mathrm{C}$, from $20^{\circ} \mathrm{C}$ to 120 ${ }^{\circ} \mathrm{C}$, and from $20^{\circ} \mathrm{C}$ to $140{ }^{\circ} \mathrm{C}$, are shown in Table 1 .

The linear dependences of $a_{\mathrm{w}}$ and of $\lambda_{\mathrm{ws}}=\lambda_{\mathrm{w}}$ on $t$ (Deliiski, 2003, 2013a, 2013b; Deliiski et al., 2015) allow for the solution of the mathematical model using the average arithmetic values of $a_{\mathrm{w}}$ and $\lambda_{\mathrm{ws}}=\lambda_{\mathrm{w}}$ in respective temperature ranges (Table 1 ) for the determination of the temperature distribution along the details thickness during unilateral heating of the details.

Simultaneously with the computation of the nonstationary distribution of $t$ along the details thickness, calculations of $t_{\text {avg }}, t_{\text {ws }}, \alpha, q_{\mathrm{w}}, q_{\mathrm{e}}, q_{\text {total }}, \mathrm{d} q_{\mathrm{w}} / \mathrm{d} \tau, \mathrm{d} q_{\mathrm{e}} / \mathrm{d} \tau$, and $\mathrm{d} q_{\text {total }} / \mathrm{d} \tau$ were carried out, using the value of the density $\rho_{\mathrm{w}}=445.6 \mathrm{~kg} \cdot \mathrm{m}^{-3}$ and average arithmetic values of the specific heat capacity $c_{\mathrm{w}}$ given in the last row of Table 1 in respective temperature ranges. This value of $\rho_{w}$ is calculated according to eq. (11) for spruce wood with $u$ $=0.15 \mathrm{~kg} \cdot \mathrm{kg}^{-1}, u_{\mathrm{fsp}}^{293.15}=0.32 \mathrm{~kg} \cdot \mathrm{kg}^{-1}, \rho_{\mathrm{b}}=380 \mathrm{~kg} \cdot \mathrm{m}^{-}$ 3 , and $S_{\mathrm{v}}=11.4 \%$ (Nikolov and Videlov, 1987). The values of $c_{\mathrm{w}}$ were calculated according to the mathematical description of the specific heat capacity of the non-frozen wood in the hygroscopic range given in (Deliiski, 2003, 2011, 2013b). Because of the almost linear dependence of $c_{\mathrm{w}}$ on $t$, the average arithmetic values of $c_{\mathrm{w}}$ for the respective temperature ranges were used during the solution of eqs. (24) and (29).

The left part of Figure 2 presents the temperature change calculated by the model in 4 characteristic points, equidistant from one another, along the thickness of the detail with $h=8 \mathrm{~mm}$ during its unilateral heating at $t_{\mathrm{m}}=140{ }^{\circ} \mathrm{C}$. The coordinates of these points are shown in the legend of the figure. The right part of this figure shows the change in $t_{\text {avg }}$ of the details during their heating at $t_{\mathrm{m}}=140^{\circ} \mathrm{C}$, depending on $h$.

Figure 3 presents the change in the surface temperature at the non-heated side of the details, $t_{\mathrm{ws}}$, and in the heat transfer coefficient, $\alpha$, during unilateral heating at $t_{\mathrm{m}}=140{ }^{\circ} \mathrm{C}$, depending on $h$.

Figures 4,5 , and 6 present the calculated change of $q_{\mathrm{w}}, q_{\mathrm{e}}$, and $q_{\text {total }}$ during unilateral heating at $t_{\mathrm{m}}=100$ ${ }^{\circ} \mathrm{C}$ and at $t_{\mathrm{m}}=140^{\circ} \mathrm{C}$ of the spruce details with studied thicknesses.

Figures 7, 8, and 9 present the calculated change of $\mathrm{d} q_{\mathrm{w}} / \mathrm{d} \tau, \mathrm{d} q_{\mathrm{e}} / \mathrm{d} \tau$, and $\mathrm{d} q_{\text {total }} / \mathrm{d} \tau$ during unilateral heating at $t_{\mathrm{m}}=100{ }^{\circ} \mathrm{C}$ and at $t_{\mathrm{m}}=140^{\circ} \mathrm{C}$ of the spruce details with studied thicknesses.

Table 1 Change in $a_{\mathrm{w}}, \lambda_{\mathrm{w}}=\lambda_{\mathrm{ws}}$, and $c_{\mathrm{w}}$ of spruce wood with $u=0.15 \mathrm{~kg} \cdot \mathrm{kg}^{-1}$, depending on $t$

Tablica 1. Promjena vrijednosti $a_{\mathrm{w}}, \lambda_{\mathrm{w}}^{\mathrm{w}}=\lambda_{\mathrm{ws}}$, i $c_{\mathrm{w}}$ za smrekovinu sa sadržajem vode $u=0,15 \mathrm{~kg} \cdot \mathrm{kg}^{-1}$, ovisno o temperaturi $t$

\begin{tabular}{|c|c|c|c|c|c|c|c|}
\hline \multirow{2}{*}{$\begin{array}{c}\text { Wood } \\
\text { parameter } \\
\text { Svojstvo drva }\end{array}$} & \multicolumn{3}{|c|}{$\begin{array}{c}\text { Temperature } t,{ }^{\circ} \mathrm{C} \\
\text { Temperatura } t,{ }^{\circ} \mathrm{C}\end{array}$} & \multicolumn{2}{c|}{$\begin{array}{c}\text { Average arithmetic values of } \lambda_{w}, \boldsymbol{a}_{w}, \text { and } c_{\mathrm{w}} \text { for temperature ranges: } \\
\text { Prosječne vrijednosti } \lambda_{w}, a_{w}, i c_{w} \text { za raspon temperatura }\end{array}$} \\
\cline { 2 - 8 } & 20 & 60 & 100 & 140 & $t=20 \div 100{ }^{\circ} \mathrm{C}$ & $t=20 \div 120{ }^{\circ} \mathrm{C}$ & $t=20 \div 140{ }^{\circ} \mathrm{C}$ \\
\hline $\begin{array}{c}\lambda_{\mathrm{ws}}=\lambda_{\mathrm{w}} \\
\mathrm{W} \cdot \mathrm{m}^{-1} \cdot \mathrm{K}^{-1}\end{array}$ & 0.2341 & 0.2664 & 0.2987 & 0.3311 & 0.2664 & 0.2745 & 0.2826 \\
\hline $\begin{array}{c}a_{\mathrm{w}} \cdot 10^{7}, \\
\mathrm{~m}^{2} \cdot \mathrm{s}^{-1}\end{array}$ & 2.5799 & 2.7412 & 2.8818 & 3.0052 & 2.7309 & 2.7627 & 2.7926 \\
\hline $\begin{array}{c}c_{\mathrm{w}}, \\
\mathrm{J} \cdot \mathrm{kg}^{-1} \cdot \mathrm{K}^{-1}\end{array}$ & 2036 & 2181 & 2326 & 2472 & 2181 & 2218 & 2254 \\
\hline
\end{tabular}



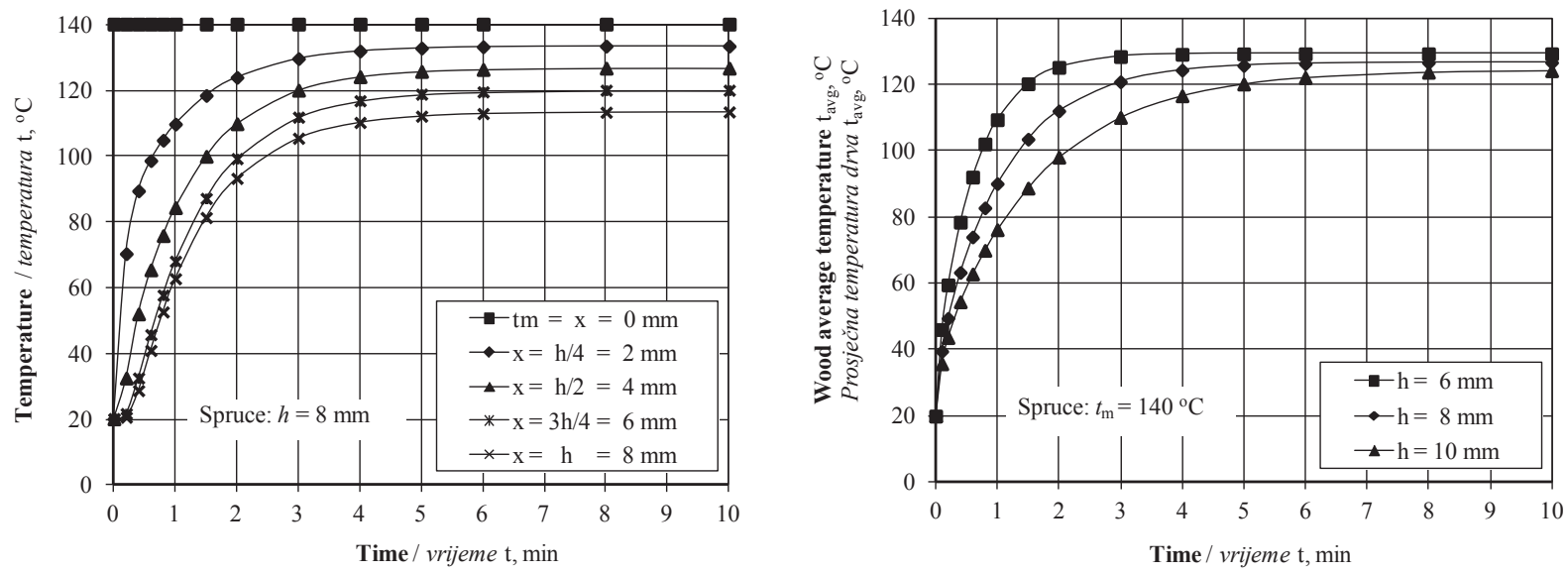

Figure 2 Change in $t$ along the detail thickness of $h=8 \mathrm{~mm}$ (left) and in $t_{\text {avg }}$ (right) of spruce details with $t_{0}=20^{\circ} \mathrm{C}, u=0.15$ $\mathrm{kg} \cdot \mathrm{kg}^{-1}, h=6 \mathrm{~mm}, h=8 \mathrm{~mm}$, and $h=10 \mathrm{~mm}$ during their unilateral heating at $t_{\mathrm{m}}=140^{\circ} \mathrm{C}$ and at $t_{\mathrm{a}}=20^{\circ} \mathrm{C}$

Slika 2. Promjena temperature $t \mathrm{u}$ smjeru debljine elementa $h=8 \mathrm{~mm}$ (lijevo) i prosječne temperature drva $t_{\text {avg }}$ (desno) smrekovih elemenata pri $t_{0}=20^{\circ} \mathrm{C}, u=0,15 \mathrm{~kg} \cdot \mathrm{kg}^{-1}, h=6 \mathrm{~mm}, h=8 \mathrm{~mm}$ i $h=10 \mathrm{~mm}$ tijekom njihova jednostranog zagrijavanja pri $t_{\mathrm{m}}=140{ }^{\circ} \mathrm{C}$ i $t_{\mathrm{a}}=20^{\circ} \mathrm{C}$
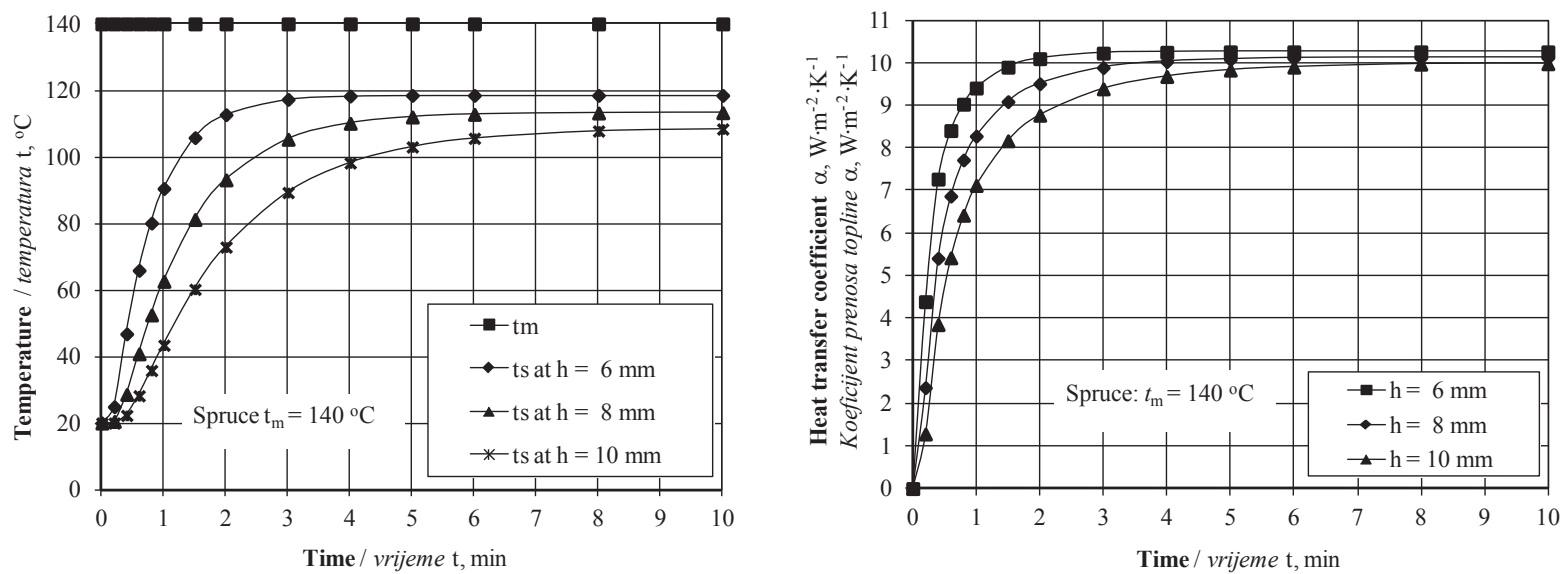

Figure 3 Change in $t_{\mathrm{ws}}$ (left) and in $\alpha$ (right) of spruce details with $t_{0}=20^{\circ} \mathrm{C}, u=0.15 \mathrm{~kg} \cdot \mathrm{kg}^{-1}$ during their unilateral heating at $t_{\mathrm{m}}=140{ }^{\circ} \mathrm{C}$ and at $t_{\mathrm{a}}=20^{\circ} \mathrm{C}$, depending on $h$

Slika 3. Promjena temperature $t_{\mathrm{ws}}$ (lijevo) i koeficijenta prijenosa topline $\alpha$ (desno) smrekovih elemenata pri $t_{0}=20^{\circ} \mathrm{C}, u=$ $0,15 \mathrm{~kg} \cdot \mathrm{kg}^{-1}$ tijekom njihova jednostranog zagrijavanja pri $t_{\mathrm{m}}=140^{\circ} \mathrm{C}$ i $t_{\mathrm{a}}=20^{\circ} \mathrm{C}$, ovisno o debljini elemenata $h$
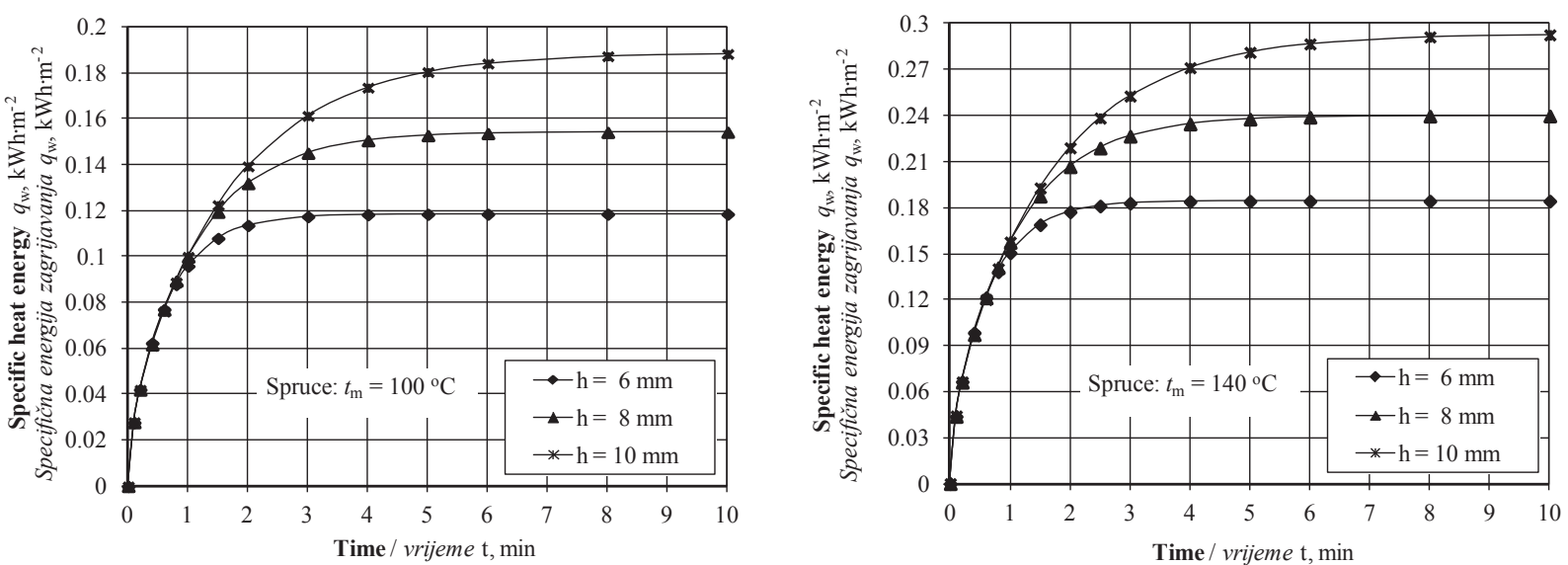

Figure 4 Change in $q_{\mathrm{w}}$ of spruce details with $t_{0}=20^{\circ} \mathrm{C}$ and $u=0.15 \mathrm{~kg} \cdot \mathrm{kg}^{-1}$ during their unilateral heating at $t_{\mathrm{m}}=100^{\circ} \mathrm{C}$ (left) and $t_{\mathrm{m}}=140{ }^{\circ} \mathrm{C}$ (right), depending on $h$

Slika 4. Promjena specifične energije zagrijavanja $q_{\mathrm{w}}$ smrekovih elemenata pri $t_{0}=20^{\circ} \mathrm{C}$ i $u=0,15 \mathrm{~kg} \cdot \mathrm{kg}^{-1}$ tijekom njihova zagrijavanja pri $t_{\mathrm{m}}=100^{\circ} \mathrm{C}$ (lijevo) i $t_{\mathrm{m}}=140{ }^{\circ} \mathrm{C}$ (desno), ovisno o debljini elemenata $h$ 

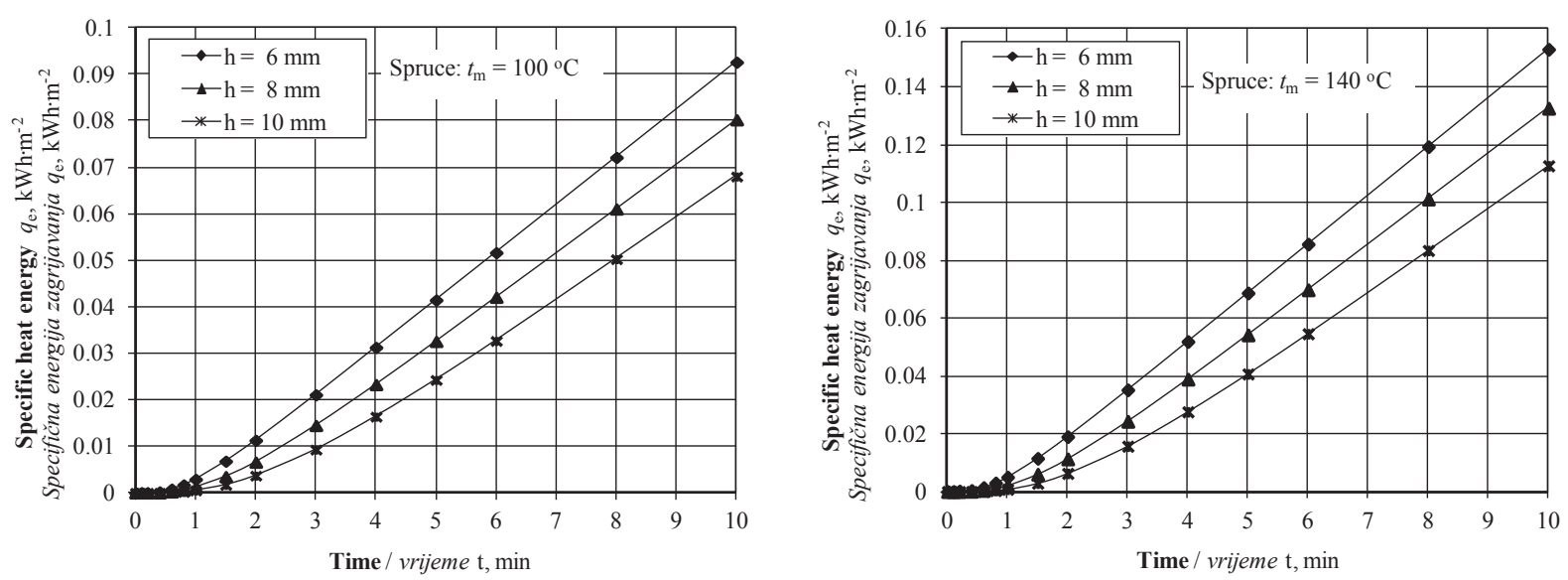

Figure 5 Change in $q_{\mathrm{e}}$ of spruce details with $t_{0}=20^{\circ} \mathrm{C}$ and $u=0.15 \mathrm{~kg} \cdot \mathrm{kg}^{-1}$ during their unilateral heating at $t_{\mathrm{m}}=100^{\circ} \mathrm{C}$ (left) and $t_{\mathrm{m}}=140^{\circ} \mathrm{C}$ (right), depending on $h$

Slika 5. Promjena specifične energije zagrijavanja $q_{\mathrm{e}}$ smrekovih elemenata pri $t_{0}=20^{\circ} \mathrm{C}$ i $u=0,15 \mathrm{~kg} \cdot \mathrm{kg}^{-1}$ tijekom njihova jednostranog zagrijavanja pri $t_{\mathrm{m}}=100^{\circ} \mathrm{C}$ (lijevo) i $t_{\mathrm{m}}=140{ }^{\circ} \mathrm{C}$ (desno), ovisno o debljini elemenata $h$

The obtained results show that during unilateral heating of the details, the change of all studied parameters of the process takes place according to complex curves.

By increasing the heating time, the curves of $t$ gradually approach asymptotically their largest values, decreasingly dependent on the remoteness of the characteristic points from the heated surface of the details. Analogously, the curves of the change in $t_{\mathrm{avg}}, \alpha, q_{\mathrm{w}}$, and $\mathrm{d} q_{\mathrm{e}} / \mathrm{d} \tau$ approach asymptotically their largest values, increasingly dependent on $t_{\mathrm{m}}$ and decreasingly dependent on $h$. The largest values of $t, t_{\text {avg }}, \alpha, q_{\mathrm{w}}$, and $\mathrm{d} q_{\mathrm{e}} / \mathrm{d} \tau$ are achieved when a stationary temperature distribution occurs along the details thickness.

The stationary temperature distribution along the thickness of the studied spruce details (with precision of up to $-0.2^{\circ} \mathrm{C}$ ) occurs upon reaching the following temperature at their non-heated side:

- for details with $h=6 \mathrm{~mm}: 86.0^{\circ} \mathrm{C}$ after heating duration of $3.5 \mathrm{~min}$ at $t_{\mathrm{m}}=100{ }^{\circ} \mathrm{C}, 102.7^{\circ} \mathrm{C}$ after heating duration of $3.8 \mathrm{~min}$ at $t_{\mathrm{m}}=120^{\circ} \mathrm{C}, 118.5^{\circ} \mathrm{C}$ after heating duration of $3.9 \mathrm{~min}$ at $t_{\mathrm{m}}=140^{\circ} \mathrm{C}$;

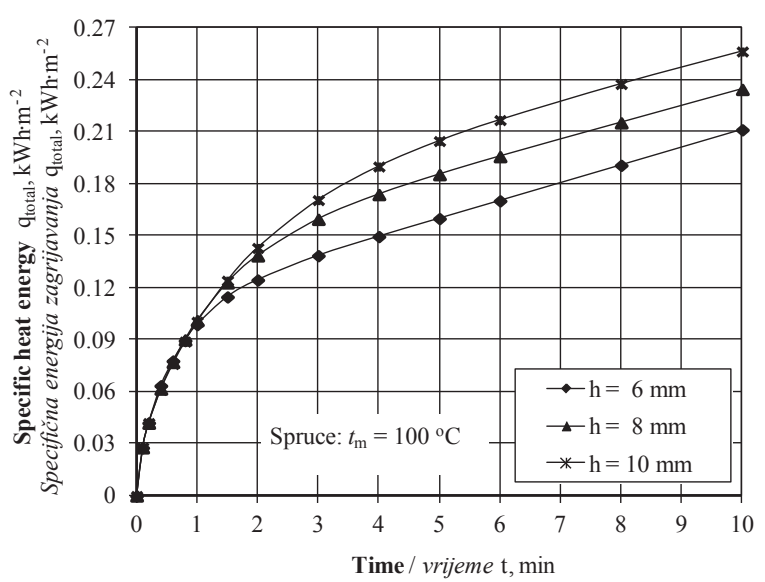

- for details with $h=8 \mathrm{~mm}: 82.7^{\circ} \mathrm{C}$ after heating duration of 6.4 min at $t_{\mathrm{m}}=100{ }^{\circ} \mathrm{C}, 98.0^{\circ} \mathrm{C}$ after heating duration of $6.7 \mathrm{~min}$ at $t_{\mathrm{m}}=120^{\circ} \mathrm{C}, 113.3^{\circ} \mathrm{C}$ after heating duration of $6.8 \mathrm{~min}$ at $t_{\mathrm{m}}=140^{\circ} \mathrm{C}$;

- for details with $h=10 \mathrm{~mm}: 79.7^{\circ} \mathrm{C}$ after heating duration of $9.7 \mathrm{~min}$ at $t_{\mathrm{m}}=100^{\circ} \mathrm{C}, 94.2^{\circ} \mathrm{C}$ after heating duration of $10.2 \mathrm{~min}$ at $t_{\mathrm{m}}=120^{\circ} \mathrm{C}, 108.7^{\circ} \mathrm{C}$ after heating duration of $10.4 \mathrm{~min}$ at $t_{\mathrm{m}}=140^{\circ} \mathrm{C}$.

At $t_{\mathrm{m}}=100{ }^{\circ} \mathrm{C}$, the most slowly changing temperature of the details surface, $t_{\mathrm{ws}}$, which is in contact with the outside air environment reaches temperatures of $50{ }^{\circ} \mathrm{C}, 60^{\circ} \mathrm{C}, 70^{\circ} \mathrm{C}$ and $80^{\circ} \mathrm{C}$, which are necessary for the start of the bending of the details with different radii $R$ after a duration of unilateral heating, equal, respectively, to: $0.6 \mathrm{~min}, 0.8 \mathrm{~min}, 1.0 \mathrm{~min}$ and $1.8 \mathrm{~min}$ at $h=6 \mathrm{~mm} ; 1.1 \mathrm{~min}, 1.5 \mathrm{~min}, 2.1 \mathrm{~min}$ and $3.9 \mathrm{~min}$ at $h$ $=8 \mathrm{~mm} ; 1.7 \mathrm{~min}, 2.4 \mathrm{~min}, 3.6 \mathrm{~min}$ and $\approx 10.0 \mathrm{~min}$ at $h$ $=10 \mathrm{~mm}$.

At $t_{\mathrm{m}}=120^{\circ} \mathrm{C}$, the temperature $t_{\mathrm{ws}}$ reaches temperatures of $50{ }^{\circ} \mathrm{C}, 60^{\circ} \mathrm{C}, 70^{\circ} \mathrm{C} 80{ }^{\circ} \mathrm{C}$ and $90^{\circ} \mathrm{C}$, after a duration of one sided heating, equal, respectively, to: $0.5 \mathrm{~min}, 0.6 \mathrm{~min}, 0.8 \mathrm{~min}, 1.0 \mathrm{~min}$ and $1 . \mathrm{min}$ at $h=6$

Figure 6 Change in $q_{\text {total }}$ of spruce details with $t_{0}=20{ }^{\circ} \mathrm{C}$ and $u=0.15 \mathrm{~kg} \cdot \mathrm{kg}^{-1}$ during their unilateral heating at $t_{\mathrm{m}}=100{ }^{\circ} \mathrm{C}$ (left) and $t_{\mathrm{m}}=140{ }^{\circ} \mathrm{C}$ (right), depending on $h$

Slika 6. Promjena specifične energije zagrijavanja $q_{\text {total }}$ smrekovih elemenata pri $t_{0}=20^{\circ} \mathrm{C}$ i $u=0,15 \mathrm{~kg} \cdot \mathrm{kg}^{-1}$ tijekom njihova jednostranog zagrijavanja pri $t_{\mathrm{m}}=100^{\circ} \mathrm{C}$ (lijevo) i $t_{\mathrm{m}}=140{ }^{\circ} \mathrm{C}$ (desno), ovisno o debljini elemenata $h$ 

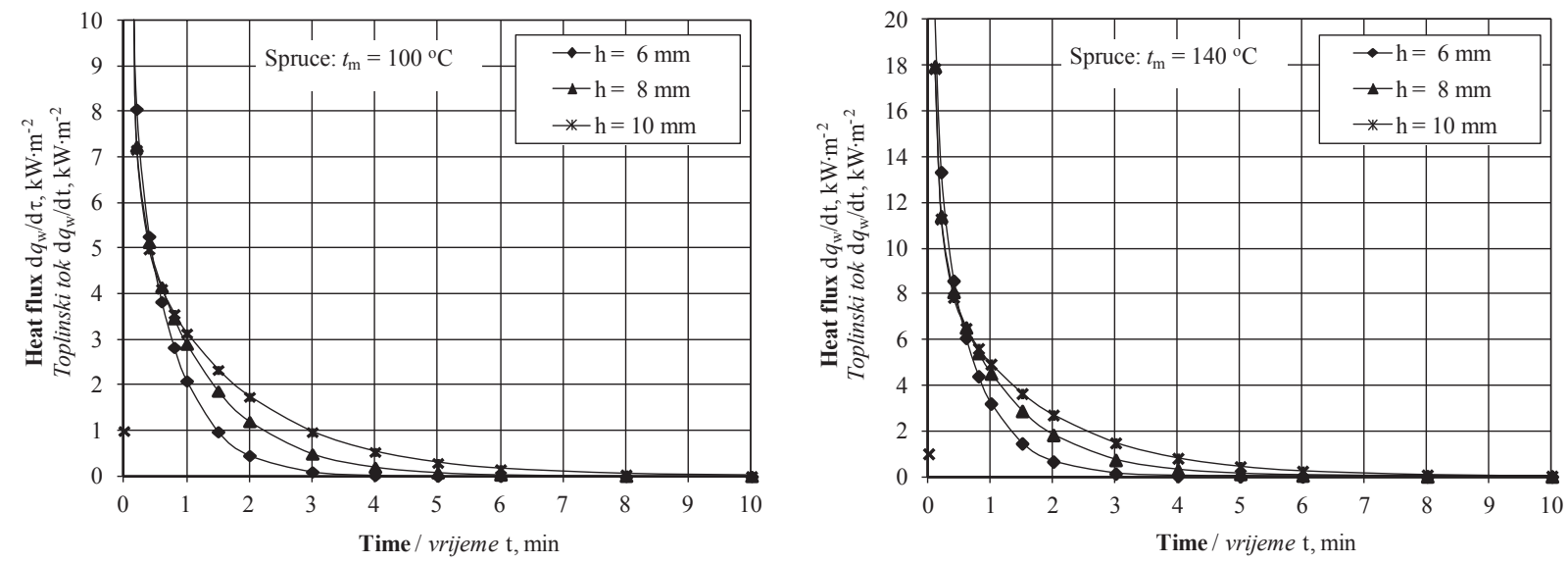

Figure 7 Change in $\mathrm{d} q_{\mathrm{w}} / \mathrm{d} \tau$ of spruce details with $t_{0}=20^{\circ} \mathrm{C}$ and $u=0.15 \mathrm{~kg} \cdot \mathrm{kg}^{-1}$ during their unilateral heating at $t_{\mathrm{m}}=100^{\circ} \mathrm{C}$ (left) and $t_{\mathrm{m}}=140^{\circ} \mathrm{C}$ (right), depending on $h$

Slika 7. Promjena toplinskog toka $\mathrm{d} q_{\mathrm{w}} / \mathrm{d} \tau$ smrekovih elemenata pri $t_{0}=20^{\circ} \mathrm{C}$ i $u=0,15 \mathrm{~kg} \cdot \mathrm{kg}^{-1}$ tijekom njihova jednostranog zagrijavanja pri $t_{\mathrm{m}}=100{ }^{\circ} \mathrm{C}$ (lijevo) i $t_{\mathrm{m}}=140{ }^{\circ} \mathrm{C}$ (desno), ovisno o debljini elemenata $h$
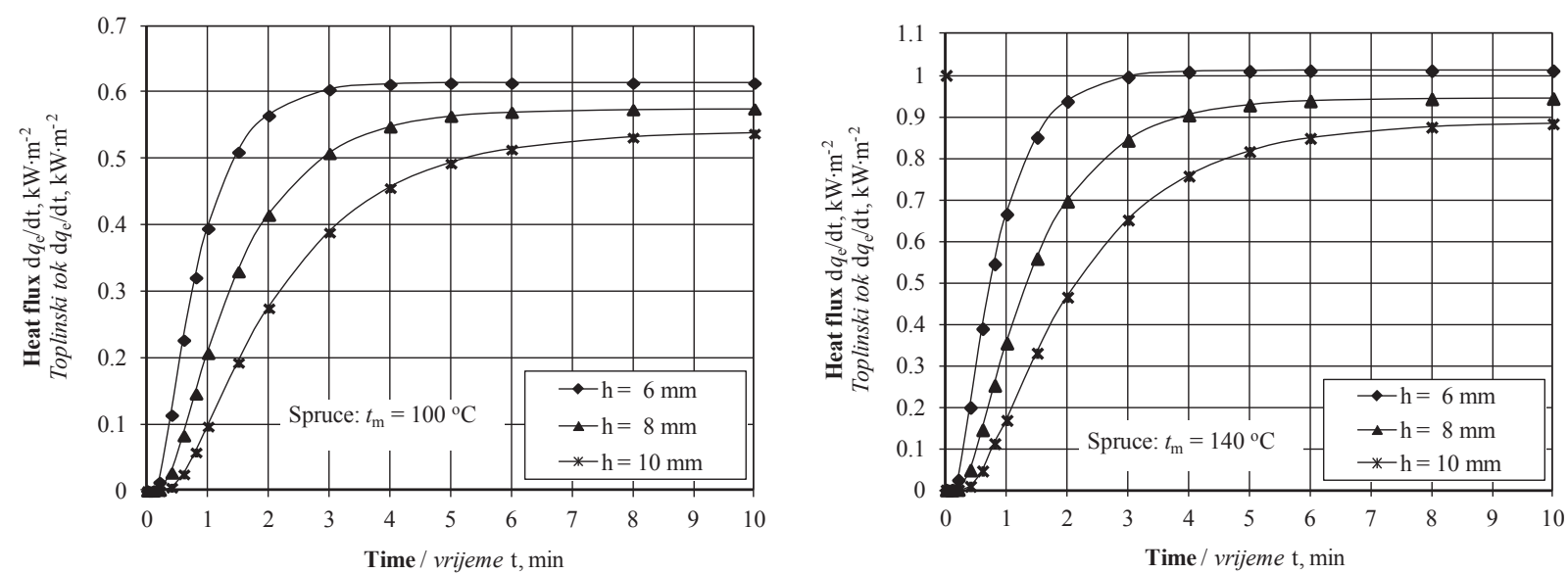

Figure 8 Change in $\mathrm{d} q_{\mathrm{e}} / \mathrm{d} \tau$ of spruce details with $t_{0}=20^{\circ} \mathrm{C}$ and $u=0.15 \mathrm{~kg} \cdot \mathrm{kg}^{-1}$ during their unilateral heating at $t_{\mathrm{m}}=100{ }^{\circ} \mathrm{C}$ (left) and $t_{\mathrm{m}}=140{ }^{\circ} \mathrm{C}$ (right), depending on $h$

Slika 8. Promjena toplinskog toka $\mathrm{d} q_{\mathrm{e}} / \mathrm{d} \tau$ smrekovih elemenata pri $t_{0}=20^{\circ} \mathrm{C}$ i $u=0,15 \mathrm{~kg} \cdot \mathrm{kg}^{-1}$ tijekom njihova jednostranog zagrijavanja pri $t_{\mathrm{m}}=100{ }^{\circ} \mathrm{C}$ (lijevo) i $t_{\mathrm{m}}=140{ }^{\circ} \mathrm{C}$ (desno), ovisno o debljini elemenata $h$
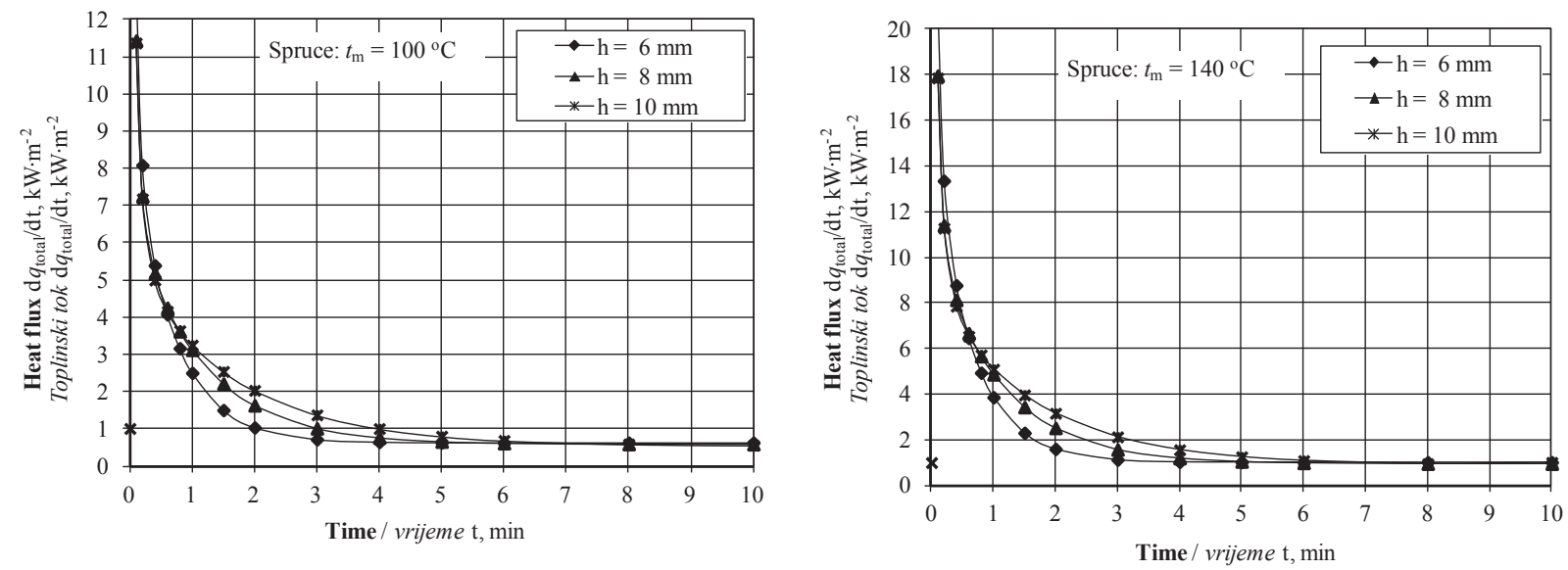

Figure 9 Change in $\mathrm{d} q_{\text {total }} / \mathrm{d} \tau$ of spruce details with $t_{0}=20{ }^{\circ} \mathrm{C}$ and $u=0.15 \mathrm{~kg} \cdot \mathrm{kg}^{-1}$ during their unilateral heating at $t_{\mathrm{m}}=100$ ${ }^{\circ} \mathrm{C}$ (left) and $t_{\mathrm{m}}=140{ }^{\circ} \mathrm{C}$ (right), depending on $h$

Slika 9. Promjena toplinskog toka $\mathrm{d} q_{\text {total }} / \mathrm{d} \tau$ smrekovih elemenata pri $t_{0}=20^{\circ} \mathrm{C}$ i $u=0,15 \mathrm{~kg} \cdot \mathrm{kg}^{-1}$ tijekom njihova jednostranog zagrijavanja pri $t_{\mathrm{m}}=100^{\circ} \mathrm{C}$ (lijevo) i $t_{\mathrm{m}}=140^{\circ} \mathrm{C}$ (desno), ovisno o debljini elemenata $h$ 
$\mathrm{mm}$; $0.9 \mathrm{~min}, 1.2 \mathrm{~min}, 1.5 \mathrm{~min}, 2.0 \mathrm{~min}$ and $2.9 \mathrm{~min}$ at $h=8 \mathrm{~mm} ; 1.4 \mathrm{~min}, 1.8 \mathrm{~min}, 2.4 \mathrm{~min}, 3.3 \mathrm{~min}$ and 5.3 $\min$ at $h=10 \mathrm{~mm}$.

At $t_{\mathrm{m}}=140{ }^{\circ} \mathrm{C}$, the temperature $t_{\mathrm{ws}}$ reaches temperatures of $50{ }^{\circ} \mathrm{C}, 60{ }^{\circ} \mathrm{C}, 70^{\circ} \mathrm{C} 80{ }^{\circ} \mathrm{C}, 90^{\circ} \mathrm{C}$ and 100 ${ }^{\circ} \mathrm{C}$, after a duration of heating, equal, respectively, to: $0.4 \mathrm{~min}, 0.5 \mathrm{~min}, 0.6 \mathrm{~min}, 0.8 \mathrm{~min}, 1.0 \mathrm{~min}$ and $1.3 \mathrm{~min}$ at $h=6 \mathrm{~mm} ; 0.8 \mathrm{~min}, 1.0 \mathrm{~min}, 1.2 \mathrm{~min}, 1.5 \mathrm{~min}, 1.9$ $\min$ and $2.5 \mathrm{~min}$ at $h=8 \mathrm{~mm} ; 1.2 \mathrm{~min}, 1.5 \mathrm{~min}, 1.9$ min, $2.5 \mathrm{~min}, 3.1 \mathrm{~min}$ and $4.3 \mathrm{~min}$ at $h=10 \mathrm{~mm}$.

By increasing the heating time, $q_{\mathrm{e}}$ and $q_{\text {total }}$ increase according to curvilinear dependences, which change into linear after the reaching of stationary distribution of $t$ along the details thickness. The slopes of the linear sections of dependences $q_{\mathrm{e}}=f(\tau)$ and $q_{\text {total }}=$ $f(\tau)$ are proportional to $t_{\mathrm{m}}$

The values of $q_{\text {total }}$ are increasingly dependent on $t_{\mathrm{m}}$ and decreasingly dependent on $h$. For example, after 10 min duration of unilateral heating, $q_{\text {total }}$ reaches the following values:

- for details with $h=6 \mathrm{~mm}: q_{\text {total }}=0.2115 \mathrm{kWh} \cdot \mathrm{m}^{-2}$ at $t_{\mathrm{m}}=100{ }^{\circ} \mathrm{C}, q_{\text {total }}=0.2730 \mathrm{kWh} \cdot \mathrm{m}^{-2}$ at $t_{\mathrm{m}}=120^{\circ} \mathrm{C}$, and $q_{\text {total }}=0.3372 \mathrm{kWh} \cdot \mathrm{m}^{-2}$ at $t_{\mathrm{m}}=140{ }^{\circ} \mathrm{C}$;

- for details with $h=8 \mathrm{~mm}: q_{\text {total }}=0.2350 \mathrm{kWh} \cdot \mathrm{m}^{-2}$ at $t_{\mathrm{m}}=100{ }^{\circ} \mathrm{C}, q_{\text {total }}=0.3022 \mathrm{kWh} \cdot \mathrm{m}^{-2}$ at $t_{\mathrm{m}}=120^{\circ} \mathrm{C}$, and $q_{\text {total }}=0.3723 \mathrm{kWh} \cdot \mathrm{m}^{-2}$ at $t_{\mathrm{m}}=140^{\circ} \mathrm{C}$;

- for details with $h=10 \mathrm{~mm}: q_{\text {total }}=0.2569 \mathrm{kWh} \cdot \mathrm{m}^{-2}$ at $t_{\mathrm{m}}=100{ }^{\circ} \mathrm{C}, q_{\text {total }}=0.3260 \mathrm{kWh} \cdot \mathrm{m}^{-2}$ at $t_{\mathrm{m}}=120^{\circ} \mathrm{C}$, and $q_{\text {total }}=0.4053 \mathrm{kWh} \cdot \mathrm{m}^{-2}$ at $t_{\mathrm{m}}=140{ }^{\circ} \mathrm{C}$.

The change of $\mathrm{d} q_{\mathrm{w}} / \mathrm{d} \tau$ and $\mathrm{d} q_{\text {total }} / \mathrm{d} \tau$ during the heating time also takes place according to complex curves. In the beginning of heating, these parameters increase rapidly to values, which are beyond the grading of the Y-axis in Fig. 7 and Fig. 9. This rapid increase of $\mathrm{d} q_{\mathrm{w}} / \mathrm{d} \tau$ and $\mathrm{d} q_{\text {total }} / \mathrm{d} \tau$ corresponds to the steep initial sections of dependencies $q_{\mathrm{w}}=f(\tau)$ and $q_{\text {total }}=f(\tau)$. After reaching their maximum values, the heat fluxes $\mathrm{d} q_{\mathrm{w}} / \mathrm{d} \tau$ and $\mathrm{d} q_{\text {total }} / \mathrm{d} \tau$ begin to decrease - initially very sharply and then more smoothly. When a stationary distribution of $t$ along the details thickness occurs, $\mathrm{d} q_{\mathrm{w}} /$ $\mathrm{d} \tau$ becomes equal to 0 . Then $\mathrm{d} q_{\text {total }} / \mathrm{d} \tau$ approaches asymptotically its lowest values, increasingly dependent on $t_{\mathrm{m}}$ and decreasingly dependent on $h$. For example, these lowest values of $\mathrm{d} q_{\text {total }} / \mathrm{d} \tau$ for $h=10 \mathrm{~mm}$ are equal to $0.552 \mathrm{~kW} \cdot \mathrm{m}^{-2}$ at $t_{\mathrm{m}}=100{ }^{\circ} \mathrm{C}$, to $0.726 \mathrm{~kW} \cdot \mathrm{m}^{-2}$ at $t_{\mathrm{m}}=$ $120{ }^{\circ} \mathrm{C}$, and to $0.905 \mathrm{~kW} \cdot \mathrm{m}^{-2}$ at $t_{\mathrm{m}}=140{ }^{\circ} \mathrm{C}$.

Using the values of $q_{\text {total }}$ and $\mathrm{d} q_{\text {total }} / \mathrm{d} \tau$, the minimum necessary power of the heating metal band (refer to Fig. 1) can be determined depending on the desired duration of unilateral heating of details at given values for $t_{\mathrm{m}}, h$ and $R / h$.

\section{CONCLUSIONS}

\section{ZAKLJUČAK}

This paper presents a methodology for mathematical modeling and research of two mutually connected problems: the temperature distribution in flat wood details subjected to unilateral heating and the energy consumption of this process.

The paper describes the development and solution of a 1-dimensional mathematical model of the transient linear heat conduction in flat wood details during their unilateral heating at arbitrary initial and boundary conditions encountered in the practice. Heat distribution along the thickness of wood details from any wood species subjected to such heating is described by the 1D partial differential equation of heat conduction. For the solution of the model, an explicit form of the finite-difference method is used.

Based on the integration of the model's solutions, for the first time a numerical approach is suggested for the computation of the specific energy consumption (for $1 \mathrm{~m}^{2}$ ) and the specific heat flux needed for the heating of the details and for the covering of their heat emission during unilateral heating aimed at wood plasticizing and bending.

For the numerical solution of the mathematical model, a software program was prepared in FORTRAN in the calculation environment of Visual Fortran Professional.

The paper shows and analyzes diagrams of a 1D non-stationary and stationary distribution of the temperature along the thickness of flat spruce details subjected to unilateral heating in order to be plasticized before their bending for the production of outside parts for the bodies of string musical instruments. It also shows and analyzes the change of the total specific energy consumption, $q_{\text {total }}$, and its components, and of the total specific heat flux, $\mathrm{d} q_{\text {total }} / \mathrm{d} \tau$, and its components needed for unilateral heating of details. All diagrams are drawn using the results calculated by the model.

The 1D distribution of the temperature and the change of $q_{\text {total }}, \mathrm{d} q_{\text {total }} / \mathrm{d} \tau$ and of their components for flat spruce details with thickness of $6 \mathrm{~mm}, 8 \mathrm{~mm}$ and $10 \mathrm{~mm}$, initial wood temperature of $20^{\circ} \mathrm{C}$, and moisture content of $0.15 \mathrm{~kg} \cdot \mathrm{kg}^{-1}$ during their unilateral heating of $10 \mathrm{~min}$ at temperatures of the heating metal body of $t_{\mathrm{m}}=100^{\circ} \mathrm{C}, t_{\mathrm{m}}=120^{\circ} \mathrm{C}, t_{\mathrm{m}}=140^{\circ} \mathrm{C}$, and temperature of the air near the non-heated side of the details of $t_{\mathrm{a}}=20^{\circ} \mathrm{C}$ have been calculated, visualized and analyzed using the model.

The suggested methodology and algorithm for its realization, as well as the results obtained from the computer solutions of the model could be used for the following purposes:

- Visualization and technological analysis of the temperature change along the thickness of details from different wood species with different thickness and moisture content during their unilateral heating before bending accomplished by a heating body with different temperatures;

- Determination of the time of details heating, which is necessary for achieving the minimum required plasticity of the details before their bending with a specified radius and $R / h$ ratio;

- Computation of the energy consumption of the details at each moment of their unilateral heating;

- Determination of the necessary power of the heating metal body depending on the desired duration of unilateral heating of details at given values for $t_{\mathrm{m}}, h$ и $R / h$; - Creation of a scientifically derived model-based automatic control of the unilateral heating process. 
The mathematical model could be input into the software of programmable controllers for model predictive automatic control (Deliiski, 2004; Hadjiski, 2013; Hadjiski and Deliiski, 2015) of unilateral heating of wood details used for different purposes after the bending of the details.

The methodology for the development and solution of the model could be further applied in the creation of analogous models, for example, for the calculation of the change of the temperature and energy consumption in flat details during their heating before lacquering (Deliiski et al., 2016a) or in equipment walls made of various materials.

\section{Acknowledgement - Zahvala}

This document was supported by the grant No BG051PO001-3.3.06-0056, financed by the Human Resources Development Operational Programme (2007 - 2013) and co-financed jointly by the ESF of the EU and the Bulgarian Ministry of Education and Science.

\section{Symbols - Simboli}

$a \quad=$ temperature conductivity, $\mathrm{m}^{2} \cdot \mathrm{s}^{-1}$

$c \quad=$ specific heat capacity, $\mathrm{J} \cdot \mathrm{kg}^{-1} \cdot \mathrm{K}^{-1}$

$h \quad=$ thickness, $\mathrm{m}$

$M \quad$ = number of steps on the $x$-coordinate used for solving the model

$N=$ number of steps on the $\tau$-coordinate used for solving the model

$q \quad=$ specific energy consumption, $\mathrm{kWh} \cdot \mathrm{m}^{-2}$

$\mathrm{d} q / \mathrm{d} \tau=$ specific heat flux, $\mathrm{kW} \cdot \mathrm{m}^{-2}$

$R \quad=$ radius, $\mathrm{m}$

$S \quad=$ wood shrinkage, $\%$

$t=$ temperature, ${ }^{\circ} \mathrm{C}: t=T-273.15$

$T \quad=$ temperature, $\mathrm{K}: T=t+273.15$

$u \quad=$ moisture content, $\mathrm{kg} \cdot \mathrm{kg}^{-1}: u=W / 100$

$W \quad=$ moisture content, $\%: W=100 u$

$x=$ coordinate along the thickness of details: $0 \leq x$ $\leq X=h$

$\alpha \quad=$ heat transfer coefficient, $\mathrm{W} \cdot \mathrm{m}^{-2} \cdot \mathrm{K}^{-1}$

$\lambda=$ thermal conductivity, $\mathrm{W} \cdot \mathrm{m}^{-1} \cdot \mathrm{K}^{-1}$

$\rho \quad=$ density, $\mathrm{kg} \cdot \mathrm{m}^{-3}$

$\tau \quad=$ time, $\mathrm{s}$

$\Delta x=$ step on the $x$-coordinate of the model, which coincides with the thickness of wood detail subjected to heating, $\mathrm{m}$

$\Delta \tau=$ step on the $\tau$-coordinate for solution of the model, i.e. interval between time levels, $s$

$\Delta q=$ change of $q$ for time equal to $\Delta \tau, \mathrm{kWh} \cdot \mathrm{m}^{-2}$

(a) = at

\section{Subscripts / indeksi:}

a = air (air temperature near the non-heated side of wood details)

avg = average (the average mass temperature of details at a given moment of their unilateral heating or the average arithmetic values of thermo physical characteristics of wood)

b = basic (density, based on dry mass divided by green volume) e = emission (energy of heat flux needed for covering of the heat emission from the details)

fsp $=$ fiber saturation point of wood

$i=$ nodal point of the calculation mesh along detail thickness: $i=1,2,3,4,5,6,7,8,9$

$\mathrm{m}=$ medium (temperature of the heating metal band used for unilateral heating)

$\mathrm{p} \quad=$ process (duration of the whole process of unilateral heating)

total = total (energy or heat flux needed both for heating of wood and for covering of the heat emission from the details)

$\mathrm{V} \quad=$ volume (wood shrinkage)

$\mathrm{W} \quad=$ wood (energy or heat flux needed for heating of wood)

ws = wood surface (non-heated surface of wood details)

0 = initial (the average mass temperature of the details in the beginning of the heating or the time level in the beginning of the model's solution)

Superscripts / eksponenti:

$n \quad=$ time level: $n=0,1,2,3, \ldots \ldots ., N$

$293.15=$ at $293.15 \mathrm{~K}$, i.e. at $20^{\circ} \mathrm{C}$ (for the standard values of the wood fiber saturation point)

\section{REFERENCES}

\section{LITERATURA}

1. Angelski, D., 2010: Researches over the Processes of Plasticization and Bending of Furniture Wood Details. $\mathrm{PhD}$ Thesis, University of Forestry, Sofia (in Bulgarian).

2. Chudinov, B. S., 1968: Theory of Thermal Treatment of Wood. Nauka, Moscow (in Russian).

3. Deliiski, N., 2003: Modeling and Technologies for Steaming of Wood Materials in Autoclaves. DSc. Dissertation, University of Forestry, Sofia (in Bulgarian).

4. Deliiski, N., 2004: Modelling and Automatic Control of Heat Energy Consumption Required for Thermal Treatment of Logs. Drvna industrija, 55 (4): 181-199.

5. Deliiski, N., 2011: Transient Heat Conduction in Capillary Porous Bodies, p. 149-176. In: Convection and Conduction Heat Transfer. InTech Publishing House, Rijeka. http://dx.doi.org/10.5772/21424.

6. Deliiski, N., 2013a: Computation of the Wood Thermal Conductivity during Defrosting of the Wood. Wood research, 58 (4): 637-650.

7. Deliiski, N., 2013b: Modelling of the Energy Needed for Heating of Capillary Porous Bodies in Frozen and Nonfrozen States. Scholars' Press, Saarbrücken, Germany, 116 p. http://www.scholars-press.com//system/covergenerator/build/1060.

8. Deliiski, N.; Dzurenda, L., 2010: Modeling of the Thermal Processes in the Technologies for Wood Thermal Treatment. TU Zvolen, Slovakia (in Russian).

9. Deliiski, N.; Trichkov, N.; Angelski, D.; Dzurenda, L., 2014: Modelling of Energy Consumption for One Sided Heating of Wood Details Before Their Bending in Production of Stringed Music Instruments. Wood, Design \& Technology, 3 (1): 97-105.

http// www.fdme.ukim.mk/en/wood_journal/index.html.

10. Deliiski, N.; Dzurenda, L.; Tumbarkova, N.; Angelski, D., 2015: Computation of the Temperature Conductivity 
... Deliiski, Trichkov, Angelski, Dzurenda: Modeling and Energy Consumption of Unilateral...

of Frozen Wood during its Defrosting. Journal of Forest Sciences. Drvna industrija, 66 (2): 87-96. https://doi.org/10.5552/drind.2015.1351

11. Deliiski, N., Stanev, R., Angelski, D., Trichkov, N., Gochev, Z., 2016a. Heat transfer coefficients during unilateral convective heating of wood details before their lacquering. Engineering sciences, Bulgarian Academy of Sciences, 53(3): 26-42.

12. Deliiski, N.; Tumbarkova, N.; Dzurenda, L.; Brezin, V., 2016b: Numerical approach for computation of the heat and heat flux for covering of the emission in the surrounding air of subjected to unilateral heating flat wood details before their bending. Key Engineering Materials, 688: 153-159. https://doi.org/10.4028/www.scientific.net/KEM.688.153

13. Dorn, W. S.; McCracken, D. D., 1972: Numerical Methods with FORTRAN IV: Case Studies. New York, John Willey \& Sons, Inc.

14. Gaff, M.; Prokein, L., 2011: The Influence of Selected Factors on Coefficient of Wood Bendability. Annals of Warsaw University of Life Sciences, Forestry and Wood Technology, 74: 78-81.

15. Hadjiski, M., 2013: Functionality and Structure Development Advanced Industrial Control System. Automatic \& Informatics, 47(4): 7-14 (in Bulgarian).

16. Hadjiski, M.; Deliiski, N., 2015: Cost oriented suboptimal control of the thermal treatment of wood materials. IFAC-PapersOnLine 48-24 (2015): 54-59. http://dx.doi.org/10.1016/j.ifacol.2015.12.056.

17. Nikolov, S.; Videlov, H., 1987: Manual for Wood Drying. Zemizdat, Sofia (in Bulgarian).

18. Pervan, S., 2009: Technology for Treatment of Wood with Water Steam. University in Zagreb (in Croatian).

19. Požgaj, A.; Chovanec, D.; Kurjatko, S.; Babiak, M., 1997: Structure and Properties of Wood. $2^{\text {nd }}$ edition, Priroda a.s., Bratislava (in Slovak).
20. Radmanović, K.; Đukić, I.; Pervan, S., 2014: Specific Heat Capacity of Wood. Drvna industrija, 65 (2): 151155. https://doi.org/10.5552/drind.2014.1333

21. Rice, R. W.; Lucas, J., 2003: The Effect of Moisture Content and Bending Rate on the Work Required to Bend Solid Red Oak. Forest Prod. J., 53 (2): 71-77.

22. Rowell, R. M.; Konkol, P., 1987: Treatments that Enhance Physical Properties of Wood. FPL, General Technical Report FPL-GTR-55, 12 p.

23. Shubin, G. S., 1990: Drying and Thermal Treatment of Wood. Lesnaya promyshlennost, Moscow (in Russian).

24. Taylor, Z., 2001: Wood Bender's Handbook. Sterling Publ. Co., Inc., New York.

25. Telegin, A. S.; Shvydkiy, B. S.; Yaroshenko, U. G., 2002: Heat-and mass transfer. Akademkniga, Moscow (in Russian).

26. Trebula, P.; Klement, I., 2002: Drying and Hydrothermal Treatment of Wood. Technical University in Zvolen (in Slovak).

27. Videlov, H., 2003: Drying and Thermal Treatment of Wood. Publishing House of the University of Forestry, Sofia (in Bulgarian).

\section{Corresponding address:}

Prof. NENCHO DELIISKI, Ph.D., DSc.

Faculty of Forest Industry, University of Forestry

Kliment Ohridski Blvd. 10

1796 Sofia, BULGARIA

e-mail: deliiski@netbg.com 